\title{
Cell-specific expression of the prolactin gene in transgenic mice is controlled by synergistic interactions between promoter and enhancer elements
}

\author{
E. Bryan Crenshaw III, ${ }^{1,2}$ Kristin Kalla, ${ }^{2,4}$ Donna M. Simmons, ${ }^{3,4}$ Larry W. Swanson, ${ }^{3,4}$ and Michael \\ G. Rosenfeld ${ }^{2,4}$ \\ ${ }^{1}$ Department of Biology, ${ }^{2}$ Eukaryotic Regulatory Biology Program and Center for Molecular Genetics, School of Medicine, \\ University of California-San Diego, La Jolla, California 92093 USA; ${ }^{3}$ Neural Systems Laboratory, Salk Institute, La Jolla, \\ California 92037 USA; ${ }^{4}$ Howard Hughes Medical Institute, La Jolla, California 92093 USA
}

Prolactin gene expression is restricted to the lactotrophic and somatomammotrophic cells of the anterior pituitary. In transgenic mice, a fusion gene consisting of $3 \mathbf{~ k b}$ of prolactin $5^{\prime}$-flanking region fused to a firefly luciferase or human growth hormone (hGH) reporter gene is expressed at high levels with the strict tissue and cell-type specificity that is characteristic of the endogenous prolactin gene. High levels of expression require two cis-acting regions: a distal enhancer $(-1.8$ to $-1.5 \mathrm{~kb})$ and a proximal region $(-422$ to $+33 \mathrm{bp})$. Each of these regions alone can direct low levels of fusion gene expression to prolactin-producing cell types in transgenic mice, but a synergistic interaction between these regions is necessary for high levels of expression. The ontogeny of the prolactin transgene expression closely follows the appearance of high levels of a POU homeo-domain transcription factor, Pit-1, that has been shown previously to bind structurally related sequences in both the distal enhancer and proximal regions and to activate the expression of the prolactin gene in vitro. Unexpectedly, transgenes containing the distal enhancer removed from its normal context are expressed in both the prolactin-producing lactotrophs and the thyroid-stimulating hormone (TSH)-producing thyrotrophs, thereby suggesting that sequences flanking this enhancer are necessary to restrict expression to the correct cell type within the pituitary. These data indicate that distinct processes of gene activation and restriction are necessary for the fidelity of cell-type-specific expression within an organ.

[Key Words: Prolactin gene; transgenic mice; Pit-1]

Received February 22, 1989; revised version accepted April 20, 1989.

Determining the molecular mechanisms by which an undifferentiated cell progresses to the differentiated state is a central question of developmental biology. In Drosophila, powerful genetic methods have directed the search for such mechanisms to a class of genes that encode a similar 60-amino-acid sequence, referred to as the homeo domain (for review, see Akam 1987; Gehring 1987; Scott and Carroll 1987). Recently, it has been shown that several mammalian tissue-specific transcription factors also contain a homeo domain that is related distantly to the homeotic genes of Drosophila: Pit-1 regulates prolactin and growth hormone genes (Bodner et al. 1988; Ingraham et al. 1988); Oct-1 regulates several genes (Sturm et al. 1988); and Oct-2 regulates the immunoglobulin genes (Clerc et al. 1988; Ko et al. 1988; Muller et al. 1988; Scheidereit et al. 1988). Because one of these recently characterized homeo-domain transcription factors, Pit-1, regulates pituitary hormones, the developing pituitary provides an important paradigm for the role of these transcription factors during ontogeny.

The five classic cell types of the anterior pituitary develop from Rathke's pouch and appear in a stereotypical order during ontogeny (Watanabe and Daikoku 1979; Pintar and Lugo 1987). Determination of the molecular basis for the differentiation of five separate cell types from the apparently homogeneous ectodermal cell layer that gives rise to Rathke's pouch will provide insight into the mechanisms of development in mammals. Until recently, there was no direct evidence of a relationship between any cell types within the pituitary beyond their common ontogeny, but several observations suggested that the growth-hormone-producing somatotroph and the prolactin-producing lactotroph are related cell types: (1) They express evolutionarily related hormones (Cooke et al. 1981); (2) both cell types fail to develop normally in dwarf mutant mice (Wilson and Wyatt 1986); and (3) lactotrophs are derived from stem 
cells that coexpress prolactin and growth hormone (Frawley et al. 1985; Hoeffler et al. 1985; Behringer et al. 1988). More recently, it has been shown that both cell types express a common tissue-specific factor Pit-1 (Bodner et al. 1988; Ingraham et al. 1988).

Pit-1 is a homeo-domain protein that shares a second region of similarity, the POU domain, with several other transcriptional and developmental factors (Pit-1, Oct-1 and Oct-2, and unc-86; Herr et al. 1988). The POU domain is a 75 - to 82 -amino-acid region that is shared among proteins that activate transcription (Pit-1, Oct-1 and Oct-2) or that specify the differentiated phenotype and cell lineage of neurons in Caenorhabditis elegans (unc-86, Finney et al. 1988). Pit-1 binds to its cognate sequences $\left({ }_{A}^{T}{ }_{A} T_{A} T_{A}\right.$-TATNCAT) within both the growth hormone and prolactin genes (Fig. 1A; Nelson et al. 1988 ) and activates transcription from cis-acting elements of these two genes (Ingraham et al. 1988; Mangalam et al. 1989). In the growth hormone gene, two Pit-1 binding sites fall within regions that are critical for the full quantitative tissue-specific expression in cell culture (Fig. 1A; Nelson et al. 1986; West et al. 1987; Ye and Samuels 1987) and transgenic mice (Lira et al. 1988). In the prolactin gene, several Pit-1 binding sites are clustered in two regions of the $5^{\prime}$-flanking region (Nelson et al. 1988$)$; a distal enhancer $(-1.8$ to $-1.5 \mathrm{~kb})$ and a proximal enhancer $(-422$ to +33$)$. Cell transfectional analyses from our laboratory indicated that the distal enhancer is predominantly responsible for the tissuespecific expression of the prolactin gene (Elsholtz et al. 1986; Nelson et al. 1986, 1988), but other groups suggest that tissue-specific expression in cell culture requires only the proximal region (Cao et al. 1987; GuitierrezHartman et al. 1987; Lufkin and Bancroft 1987).

To establish the role of these elements in tissue-specific expression during normal development, we introduced prolactin fusion genes into transgenic mice. We find that either the proximal region alone or the distal enhancer fused to a heterologous promoter, herpes thymidine kinase $(\mathrm{TK})$ promoter, are capable of directing low levels of expression to the pituitary, but, unlike previous cell transfection data, we find that a synergistic interaction between these elements is necessary for high levels of expression in vivo. Furthermore, each of these elements will direct the expression to the appropriate cell types within the pituitary. However, when the distal enhancer is removed from its normal context, either fused to the heterologous TK promoter or placed immediately adjacent to the proximal region, it also directs expression to thyrotrophs, which express thyroidstimulating hormone (TSH). Interestingly, we find that both lactotrophs and thyrotrophs express the Pit-1 factor, thereby suggesting that the normal transcriptional activation of the prolactin gene by Pit-l is restricted in thyrotrophs. Further analyses demonstrate that Pit-1 is expressed initially during pituitary development prior to the reported appearance of thyrotrophs and to the initial expression of prolactin transgenes. On the basis of these data, we propose a model for the role of synergistic interactions between activating elements and the role of restriction in regulating prolactin gene expression in related cell types during the organogenesis of the pituitary.

\section{Results}

High expression levels and complete penetrance of fusion genes containing $3 \mathrm{~kb}$ of prolactin $5^{\prime}$-flanking region

A full 3-kb 5'-flanking region of the prolactin gene fused to the human growth hormone marker gene (3KB-hGH) or the firefly luciferase marker gene (3KB-Luc) was expressed in all transgenic pedigrees examined (Fig. 1B,C), and expression was restricted to the anterior pituitary. In $3 \mathrm{~KB}-\mathrm{hGH}$ mice, the human growth hormone (hGH) content of the pituitaries (Fig. 2) was, if anything, greater than the endogenous mouse prolactin, which ranges from 4 to $12 \mu \mathrm{g}$ per pituitary (Sinha et al. 1975). In 3KBLuc mice, high levels of luciferase activity were detected in some pedigrees, but the activity varied by three orders of magnitude among the 3KB-Luc pedigrees tested (Fig. 2). These results show that the $3 \mathrm{~KB}$ promoter construct contains all cis-acting elements necessary for high levels of expression in the pituitary glands of transgenic mice.

\section{A synergistic interaction between distal and proximal enhancers is necessary for high levels of expression in the pituitary}

The proximal elements alone conferred low levels of reporter gene expression in a small percentage of the transgenic pedigrees that were established. In constructs containing the hGH marker gene, the transgene was expressed in two of four pedigrees $(\mathrm{P}-\mathrm{hGH}$; Fig. 1C). The maximum amounts of hGH detected in P-hGH animals were 50 -fold less in the pituitary than in the $3 \mathrm{~KB}$-hGH pedigree with the lowest level of expression (Fig. 2). In transgenic mice containing a proximal region fused to the luciferase marker (P-Luc), luciferase activity was not observed in any of the eight pedigrees examined (P-Luc; Fig. 1C). The difference in the penetrance of P-hGH and $P$-Luc may in part reflect the fact that cDNA constructs are not transcribed as well as genomic constructs in transgenic mice (Brinster et al. 1988).

Inclusion of both the distal enhancer and the proximal-promoter region increased the expression of the transgene dramatically (D/P constructs; Fig. 2). In several of the $D / P$ transgenic mice, the levels of expression are equivalent to those found in constructs containing the 3 -kb flanking region. However, the overall expression of the D/P constructs is significantly less (hGH fusion genes), or somewhat less (luciferase fusion genes), than the $3 \mathrm{~KB}$ constructs, suggesting that either some further elements are necessary for full expression or that the relative position of the distal and proximal regions is critical. Although the D/P-Luc expression levels were influenced dramatically by the integration site, it is clear that the distal enhancer increases the luciferase activity in the pituitary above those of the P-Luc mice, and the distribution of expression levels among the D/P-Luc 


\section{A.}

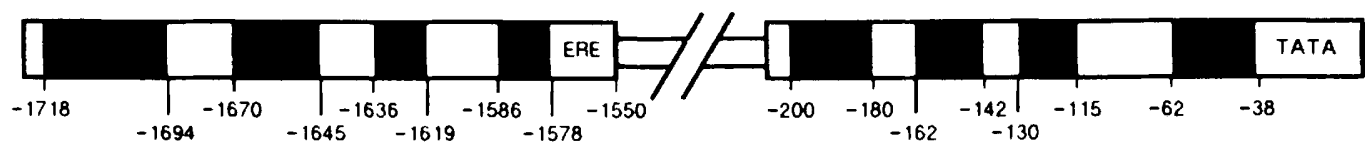

Prolactin

\section{PI 1}

Growth Hormone
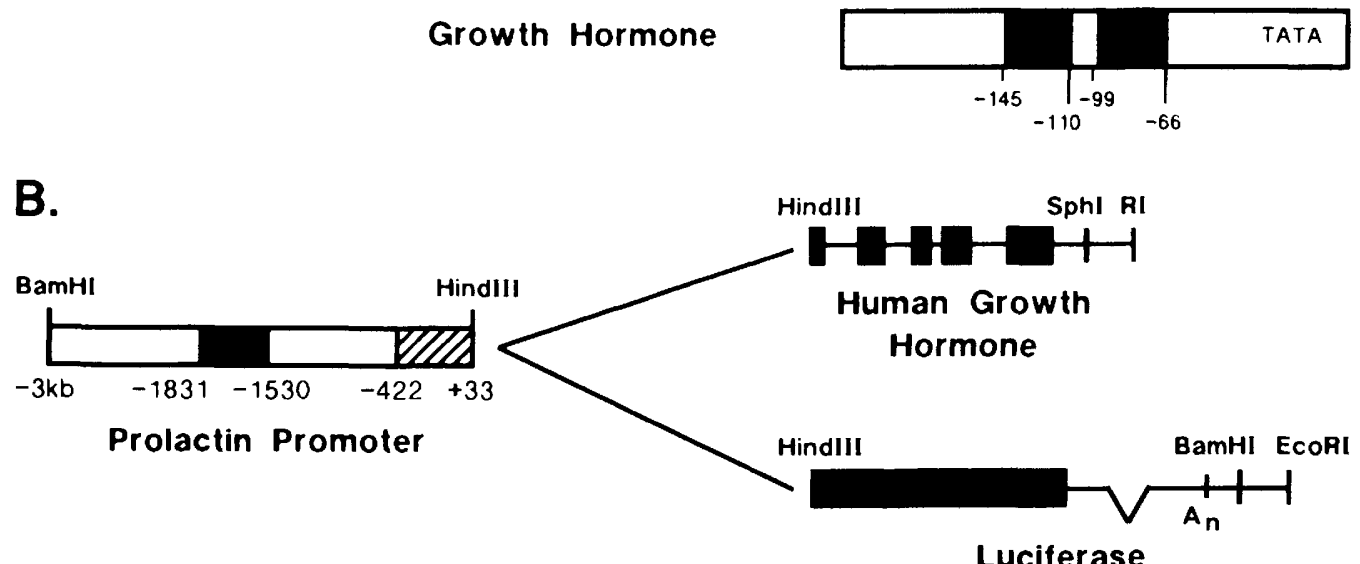

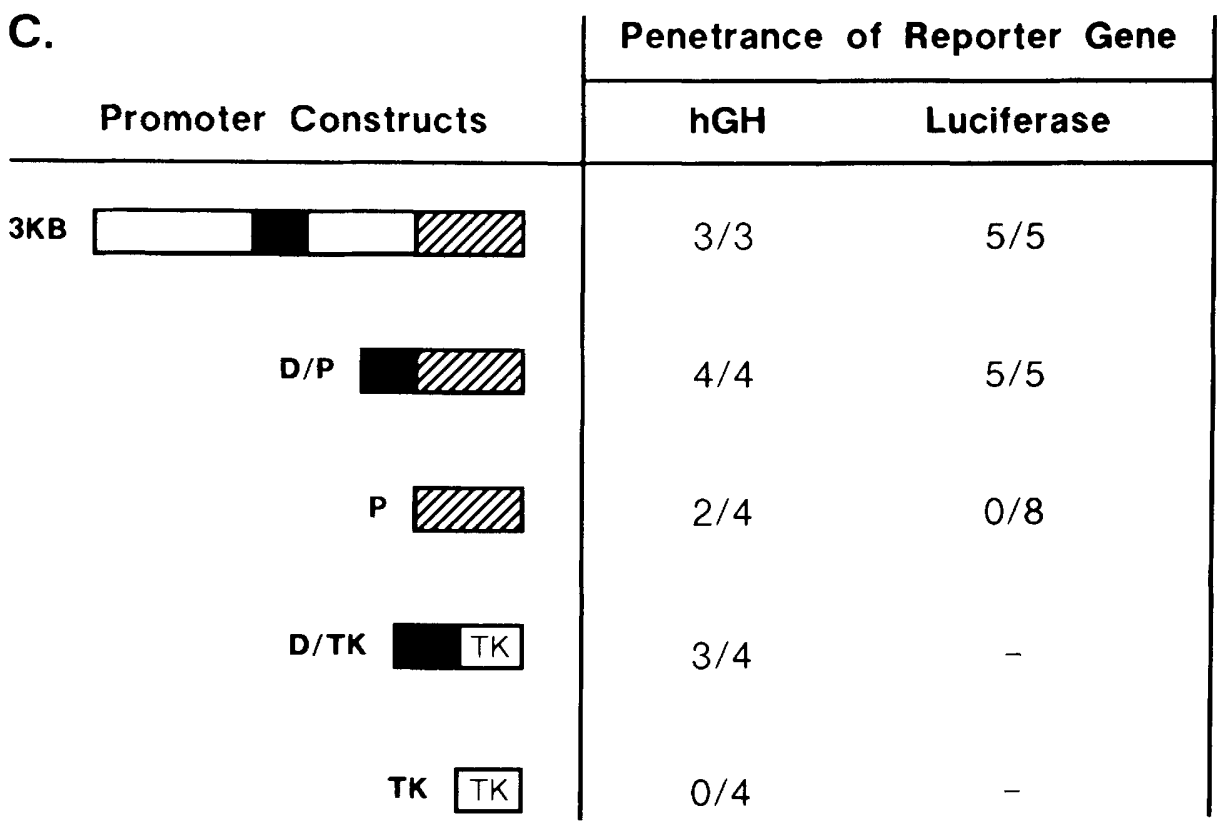

Figure 1. Schematic of the Pit-1 binding sites of prolactin and growth hormone, and the structure of the transgenic constructs and their penetrance. $(A)$ Pit-1 binding sites in prolactin and growth hormone. The homeo domain transcription factor Pit-1 binds to four sites within the distal enhancer $(-1833$ to -1531$)$ and four sites within the proximal region $(-422$ to +33$)$ (black boxes). In growth hormone, Pit-1 has two binding sites that are responsible for tissue-specific expression in the rat (Nelson et al. 1988) and in comparable locations in hGH (Bodner et al. 1987). (B) Transgenic constructs. Prolactin-promoter constructs were ligated to the reporter genes, hGH, or luciferase. Distal enhancer region between -1831 and -1530 bp in the prolactin promoter (black box); proximal elements between -422 and $+33 \mathrm{bp}$ (hatched box). The hGH reporter consists of the genomic clone from $+2 \mathrm{bp}$ to $0.5 \mathrm{~kb} 3^{\prime}$ of the polyadenylation site in exon 5 . Boxes in the hGH depict exons. The luciferase reporter consists of the cDNA for firefly luciferase (black box) linked to the splicing (V) and polyadenylation signals $\left(\mathrm{A}_{n}\right)$ from pSV2 vectors (de Wet et al. 1987). (C) Penetrance of the transgenes. Promoter constructs depict the different combinations of distal enhancer ( $\mathrm{D}$; black box), proximal elements $(\mathrm{P}$; hatched box), and the heterologous TK promoter (TK enclosed in box; -197 to $+54 \mathrm{bp}$ ) used in this study. Penetrance of reporter gene indicates the number of pedigrees expressing the reporter gene per number of pedigrees tested. Constructs not tested are shown $(-)$. The gene products of the reporter genes are detected by a immunoradiometric assay for hGH or by the light assay for luciferase (see Fig. 2). 
A.

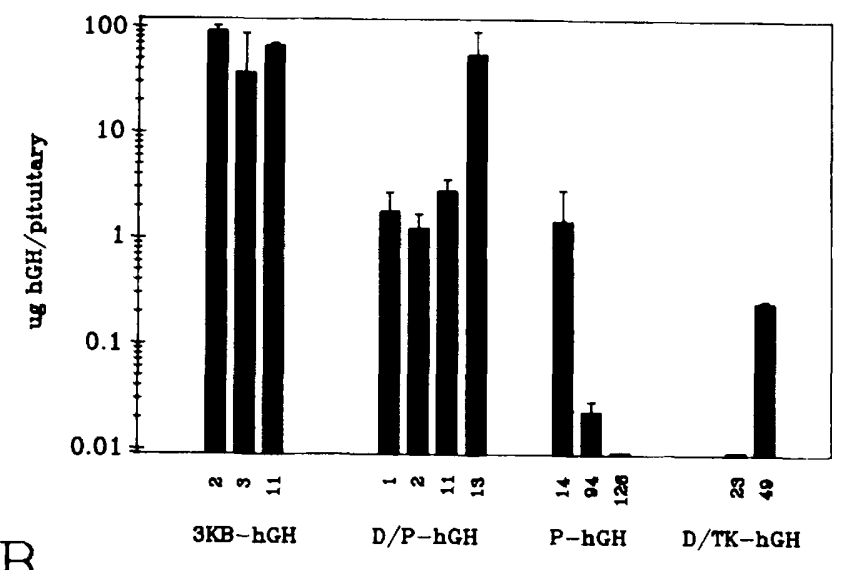

B.

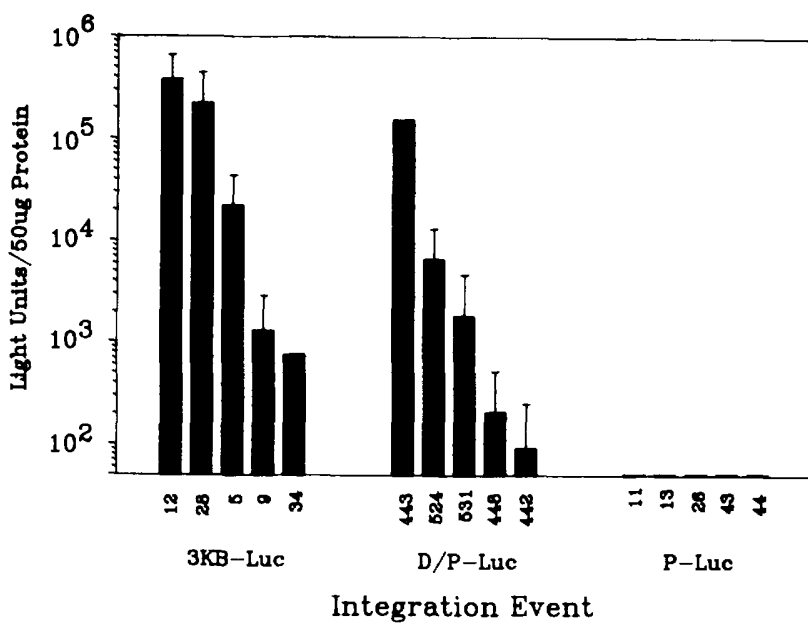

Figure 2. Luciferase activity and hGH content of pituitary glands of transgenic mice. $(A)$ The hGH content of the pituitary glands of transgenic mice containing the $3 \mathrm{~KB}-\mathrm{hGH}, \mathrm{D} / \mathrm{P}-\mathrm{hGH}$, P-hGH, or D/TK-hGH constructs (see Fig. 1C), as determined by a very sensitive immunoradiometric assay, which is specific for hGH. The mean value of the total pituitary hGH content of animals from the same transgenic pedigree (vertical bars) ( $n=3$ mice for each pedigree); numbers below the bars indicate the designation of each pedigree. The hGH levels were consistent within an integration event. Standard deviations are shown by error bars. In some pedigrees (i.e., P-hGH 126 and $\mathrm{D} / \mathrm{TK}$ hGH 23), the hGH content is below the limits of detection. $(B)$ Luciferase activity in the pituitary glands of transgenic mice containing the $3 \mathrm{~KB}-\mathrm{Luc}$, D/P-Luc, or the P-Luc constructs (see Fig. 1C). Each vertical bar represents the mean value of the luciferase activity in $50 \mu \mathrm{g}$ of protein extracted from the pituitary of animals from the same integration event $(n=6$ mice for each pedigree). Luciferase activity of transgenic pituitaries is consistent within a transgenic pedigree, but varies by as much as three orders of magnitude among different pedigrees. None of the P-Luc pedigrees have luciferase activity above the background of the assay (40-90 light units).

pedigrees is comparable to that of the 3KB-Luc mice. The distal enhancer also was capable of directing tissuespecific expression when fused to the TK promoter (D/TK-hGH; Fig. 1C), but the hGH content of the pituitary was low (Fig. 2). These results show that the distal and proximal regions each are capable of directing tissue-specific expression, but they act synergistically to generate high penetrance and high levels of expression of rat prolactin fusion genes in transgenic mice.

\section{Prolactin-promoter constructs direct tissue-specific expression}

Transgenes containing prolactin promoter constructs showed strict tissue specificity. In constructs containing the luciferase marker, luciferase activity was not found in other tissues in the mouse, except for low levels (110 light units $/ 50 \mu \mathrm{g}$ protein) in the salivary gland of a single pedigree (3KB-Luc pedigree 34; data not shown). No luciferase activity was found in any of the 12 nonpituitary tissues that were examined from five D/P-Luc pedigrees, eight P-Luc pedigrees, and the remaining four $3 \mathrm{~KB}$-Luc pedigrees. Because pituitaries from the $3 \mathrm{~KB}$-Luc mice (pedigree 12) could express $>9 \times 10^{5}$ light units in a typical light assay, and background activity in negative tissues was 40-90 light units, luciferase activity in the pituitary can be at least four orders of magnitude higher than other tissues (data not shown). In constructs containing the hGH reporter (P-hGH, D/P-hGH, D/TK$\mathrm{hGH}$, and $3 \mathrm{~KB}-\mathrm{hGH}$ ), a solution hybridization assay, using an oligonucleotide that specifically recognizes the hGH mRNA, showed that all nonpituitary tissues examined have $<5$ mRNA molecules per cell of the hGH marker gene (data not shown). Additionally, in situ hybridization analysis of the brains of $3 \mathrm{~KB}-\mathrm{hGH}$ and P-hGH animals showed that no expression is found in regions that express the metallothionein-hGH fusion gene ectopically (Russo et al. 1988). These detailed and sensitive analyses show that the expression of prolactin fusion genes reproduce the tissue specificity of the endogenous prolactin gene accurately.

\section{Three kilobases of 5'-flanking region direct cell-type specific expression within the pituitary}

To determine the cell specificity of prolactin transgene expression within the pituitary, double-label immunohistochemistry was performed with antisera against the hGH marker gene and antisera against adrenocorticotrophic hormone (ACTH), mouse growth hormone, prolactin, TSH, and luteinizing hormone (LH). Analysis of transgenic pituitaries showed that the full 3-kb flanking region or the proximal region alone directed expression of the hGH marker gene to the prolactin-containing lactotroph cell (Fig. 3, middle row), but not to the LH-producing gonadotroph cell (Fig. 4), the TSH-containing thyrotroph cell (Fig. 5, top row), or the ACTH-producing corticotroph cell (data not shown). In normal mice and rats, it has been reported that a small percentage $(1-30 \%)$ of the cells that immunostain for growth hormone also colabel with prolactin in a cell type referred to as a somatomammotroph (Frawley et al. 1985; Nikitovich-Winer et al. 1987; Behringer et al. 1988). We observed colabeling of mouse growth hormone and the marker hGH in a small percentage of cells in the 3KB- 


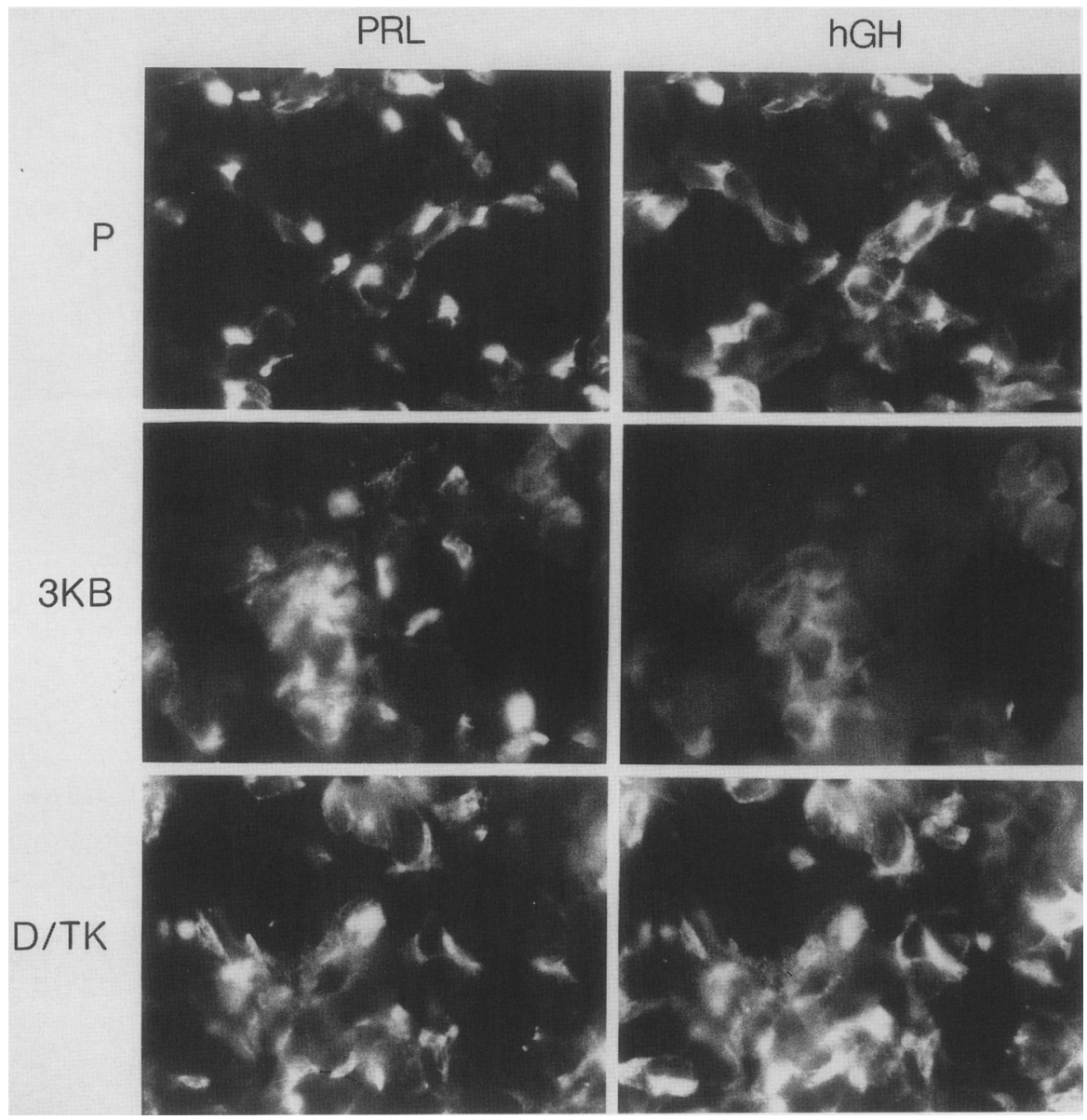

Figure 3. The hGH reporter is colocalized with prolactin in transgenic mice. Immunohistochemical staining showed that prolactin (left) colabels with the hGH reporter (right) in P-hGH (top; pedigree 14), 3KB-hGH (middle; pedigree 2), and D/TK (bottom; pedigree 49). Specific staining for the hGH marker is blocked by addition of purified hGH protein. Three to seven animals from each transgenic pedigree were analyzed by immunohistochemistry, and at least three different pedigrees from each construction were examined.

hGH animals, which is consistent with expression of the reporter gene in the somatomammotroph population (data not shown). The alternative explanation that the colabeling of the reporter gene and mouse growth hormone may reflect a small amount of transgene expression in somatotrophs cannot be excluded.

The distal enhancer directs expression to thyrotrophs when removed from its normal context

In contrast to the cell-type-specific expression directed by $3 \mathrm{~KB}-\mathrm{hGH}$ construction, transgenes in which the distal enhancer element was fused to the prolactin proximal-promoter region or fused to the heterologous TK promoter direct expression to both lactotrophs and thyrotrophs (Fig. 3, bottom row; Fig. 5, bottom row). In the 3KB-hGH mice, only 1 cell in 566 TSH-immunostained cells was stained faintly with the hGH antiserum, but $\sim 15-20 \%$ of TSH-positive cells in the three different pedigrees of D/P-hGH were stained brightly with anti$\mathrm{hGH}$ antiserum. This loss of lactotroph-specific expression in the D/P-hGH mice was not restricted to the thyrotroph cell type, because a small number $(\sim 3 \%)$ of the LH-producing gonadotroph cells also colabel for the hGH marker gene. No other construction, including 3KB-hGH, P-hGH, D/TK-hGH, or TK-hGH, was expressed in gonadotrophs. Also, expression in the ACTHproducing corticotroph cell type was not detected in any transgenic pedigree examined. In the rare integration event that expressed the hGH marker gene from the proximal-promoter region, colabeling was restricted to lactotrophs (Fig. 3, top row; and Fig. 4). The distal enhancer, therefore, can direct expression specifically to the correct tissue, but apparently it requires flanking sequences to restrict its expression to the correct cell type within the pituitary of transgenic mice (Fig. 6). Although it is possible that the juxtaposition of the distal and proximal regions has created a unusual enhancer element that functions specifically in thyrotrophs, it seems unlikely that an artifactual enhancer element would also be created when the distal element is juxtaposed with the thymidine kinase promoter.

To determine whether the hGH marker alone was sufficient to direct expression to the pituitary, we exam- 
Crenshaw et al.
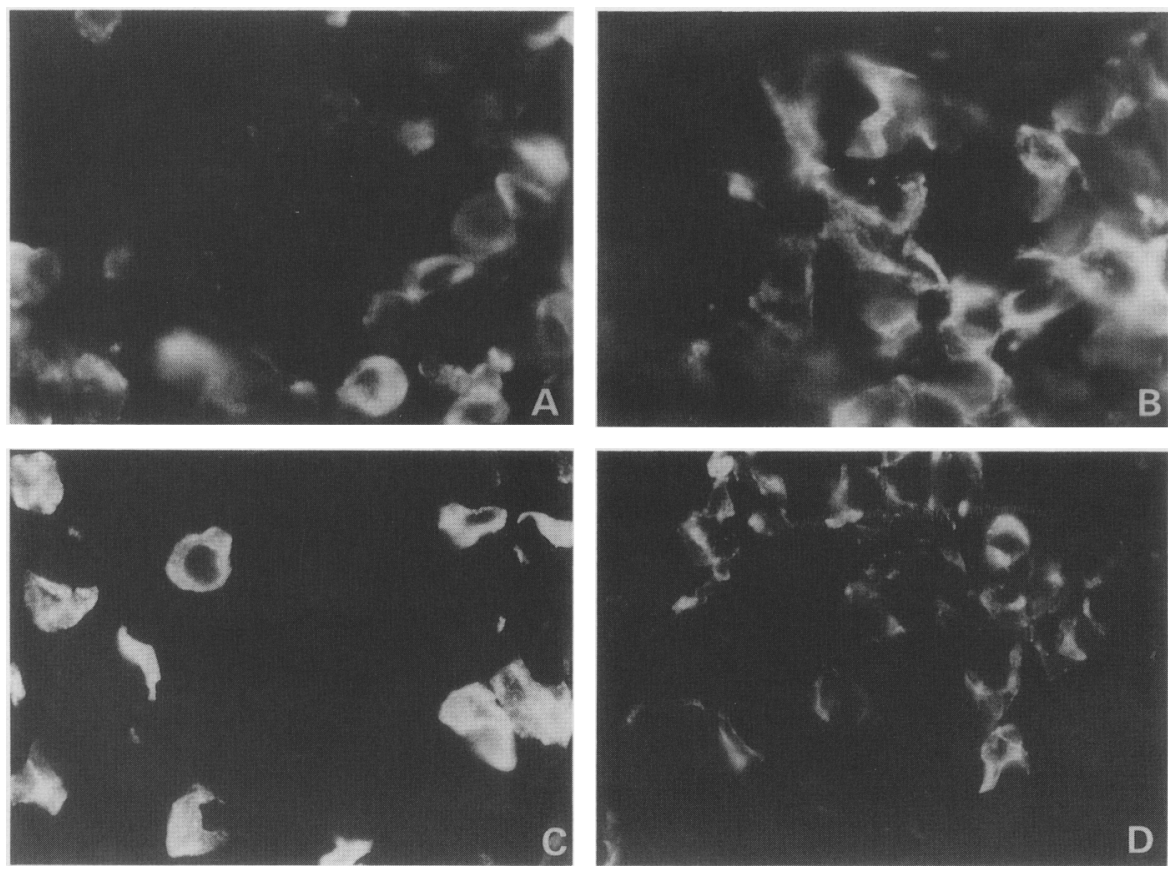

Figure 4. The hGH reporter does not express in somatotrophs or gonadotrophs. $(A, B)$ Immunohistochemical staining showed that the endogenous mouse growth hormone $(A)$ rarely colabels with the hGH reporter $(B)$ in P-hGH mice. $(C, D)$ Immunohistochemical staining showed that $\mathrm{LH}(C)$ does not colabel with the hGH reporter $(D)$ in P-hGH mice.
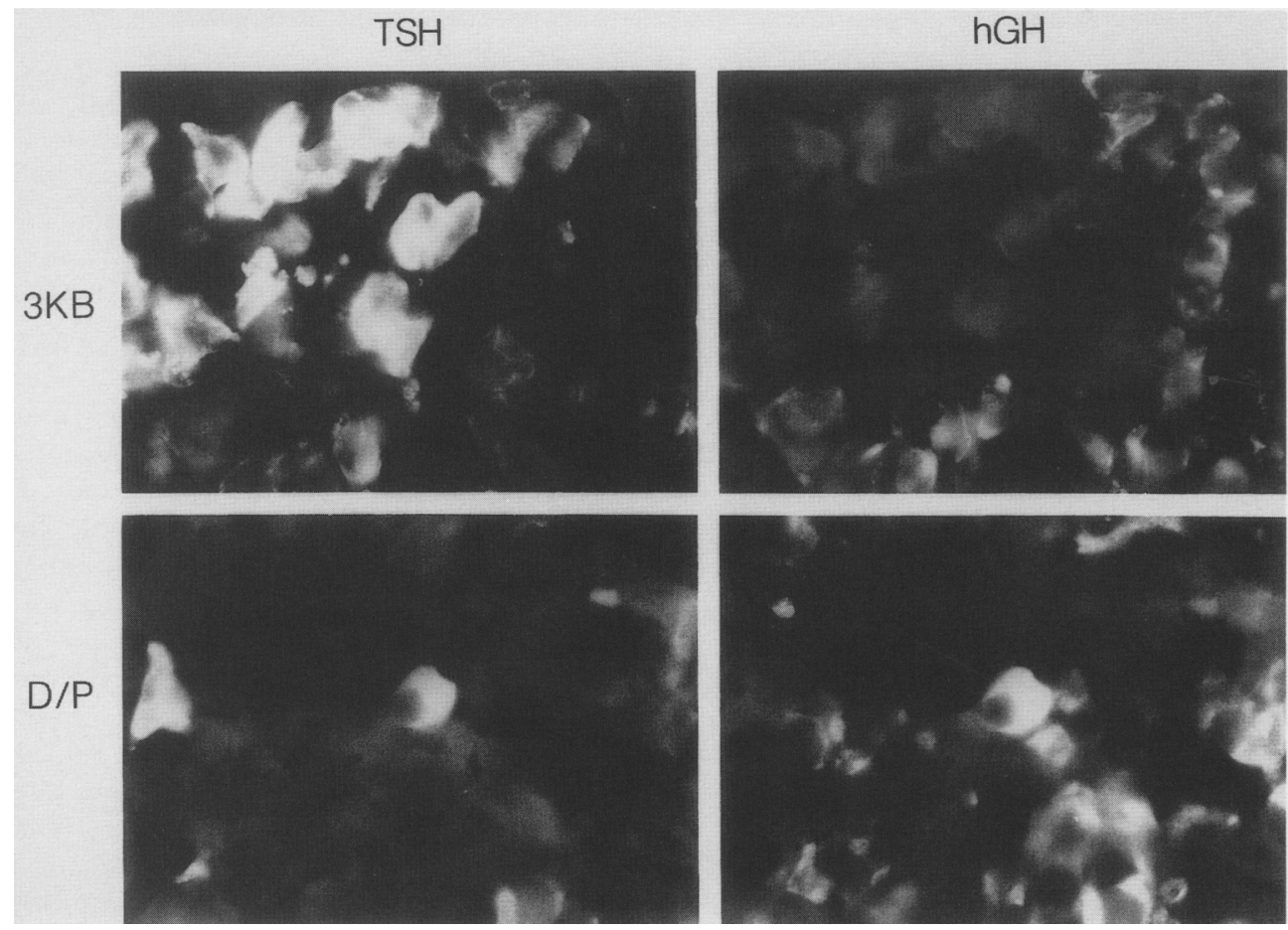

Figure 5. Double-label immunohistochemistry of hGH and TSH. In $3 \mathrm{~KB}-\mathrm{hGH}$ animals (top), the hGH reporter (right) does not colabel with TSH (left), whereas in D/P-hGH animals (bottom) hGH is found in thyrotrophs. The lower row is a representative section of $\mathrm{D} / \mathrm{P}$ animals showing that most hGH-positive cells are not thyrotrophs, and $15-20 \%$ of the thyrotrophs costain for the hGH marker gene. Six animals from four different D/P-hGH pedigrees were examined, and three to seven animals from three different 3KB-hGH pedigrees were examined. 


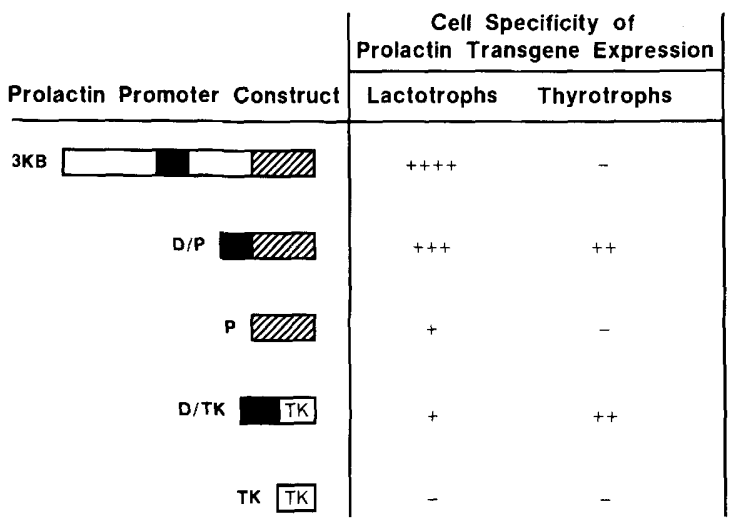

Figure 6. Cell specificity of prolactin transgene expression. The relative expression levels of the transgenic promoter constructs in lactotrophs and thyrotophs is shown. Distal enhancer (black box); proximal element (hatched box); other prolactin sequences that fall within $3 \mathrm{~kb}$ of the cap site (unfilled boxes); herpes tk promoter (box marked TK) (see legend to Fig. 1 for coordinates).

ined animals containing TK-hGH (Fig. $1 \mathrm{C})$ and a $1.3-\mathrm{kb}$ calcitonin promoter/hGH fusion gene (data not shown). No expression was observed in any cell type of the anterior pituitary (Fig. 1C and unpubl.). These data show that the hGH marker gene alone is not sufficient to direct expression to any cell type of the anterior pituitary.

\section{A tissue-specific factor responsible for prolactin expression is found in both lactotrophs and thyrotrophs}

Because it has been proposed that Pit-1 binds and activates the distal enhancer function in prolactin-producing cells (Nelson et al. 1988), we wanted to address the possibility that Pit-1 is responsible for the activation of the distal enhancer in thyrotrophs. This model would predict that Pit-1 is present in both thyrotrophs and lactotrophs, but that sequences flanking the enhancer restricted the expression of prolactin in thyrotrophs. To determine whether Pit-1 is found in thyrotrophs, we applied a double-label technique that detects Pit-1 mRNA by hybridization histochemistry of sections that previously had been immunostained for the TSH peptide using a immunoperoxidase detection method. Figure 7 shows that Pit-1 mRNA does co-localize with TSH immunostaining in a subset of thyrotrophs. Because the pituitary is composed primarily of the Pit-1-producing lactotroph and somatotroph cell types, we were concerned that the colabeling was due to the serendipitous overlap of a thyrotroph and another Pit-1-producing cell type within the pituitary sections. This possibility is unlikely because TSH and Pit-1 were co-localized also in dispersed pituitary cell cultures. In cultures that had been hybridized with Pit-1 probes, $42 \%$ of the cells that immunolabeled for TSH showed significant Pit-1 hybridization (the silver grain density above the cells was $>3$ fold above background), whereas none of the fibroblasts within these cultures showed significant hybridization.
Ontogeny of the expression of prolactin transgenes and the trans-acting factor that dictates transcriptional activation during the development of the pituitary

Because Pit-1 is a transcription factor that is expressed in multiple pituitary cell types and is homologous to homeotic genes that regulate development in Drosophila and $C$. elegans, we were interested in addressing the role of Pit-1 in the ontogeny of the pituitary. Specifically, we wanted to determine how the ontogeny of Pit-1 expression correlates with the appearance of pituitary cell types during development. Rat fetuses were sectioned, hybridized with Pit-1 probes, and autoradiographed. Figure 8 is a pseudocolor, computer-generated image of such an autoradiograph showing that the expression of Pit-1 is restricted to the developing anterior pituitary in embryonic day-16 (e16) animals. Hybridization for Pit-1 was more difficult to detect in el5 embryos. Earlier in development, Pit- 1 also occurs at e11-12 in the neural tube (He et al. 1989). These data show that Pit-1 expression is found early in the ontogeny of the pituitary prior to the reported appearance of TSH, growth hormone, and prolactin. Indeed, many reports suggest that prolactin is expressed postnatally many days after the initial expression of Pit-1, but reports vary widely in the initial ap-

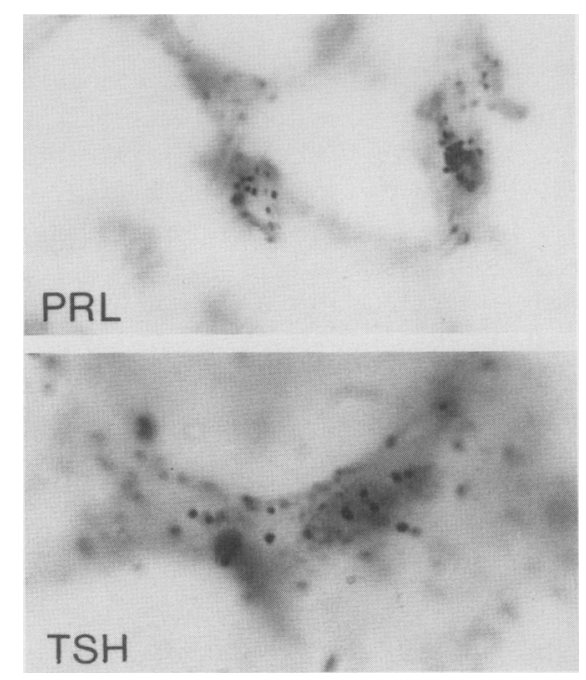

Figure 7. In situ hybridization shows that Pit-1 is expressed in cells that immunolabel for prolactin and TSH. (A) Pit-1 colocalizes with prolactin. Pituitary sections $(10 \mu \mathrm{m})$ were immunolabeled for prolactin, hybridized with a ${ }^{35} \mathrm{~S}$-labeled antisensestrand Pit-1 RNA probe, and autoradiographed as described in Materials and methods. Silver grains fall over lactotrophs, which are labeled with the immunoperoxidase reaction product. No specific hybridization was observed using the sense-strand probes. $(B)$ Pit- 1 colocalizes with TSH. This panel depicts two overlapping thyrotrophs that express Pit-1. Similar results are obtained when using probes against the coding region of Pit-1 (as shown above) or against the $3^{\prime}$-untranslated region (data not shown), thereby indicating that hybridization is specific for Pit-1 and does not represent cross-hybridization with related genes. This colabeling does not represent serendipitous overlap of cells that express Pit-1 because similar results are obtained using dispersed primary cultures of rat pituitary glands. 


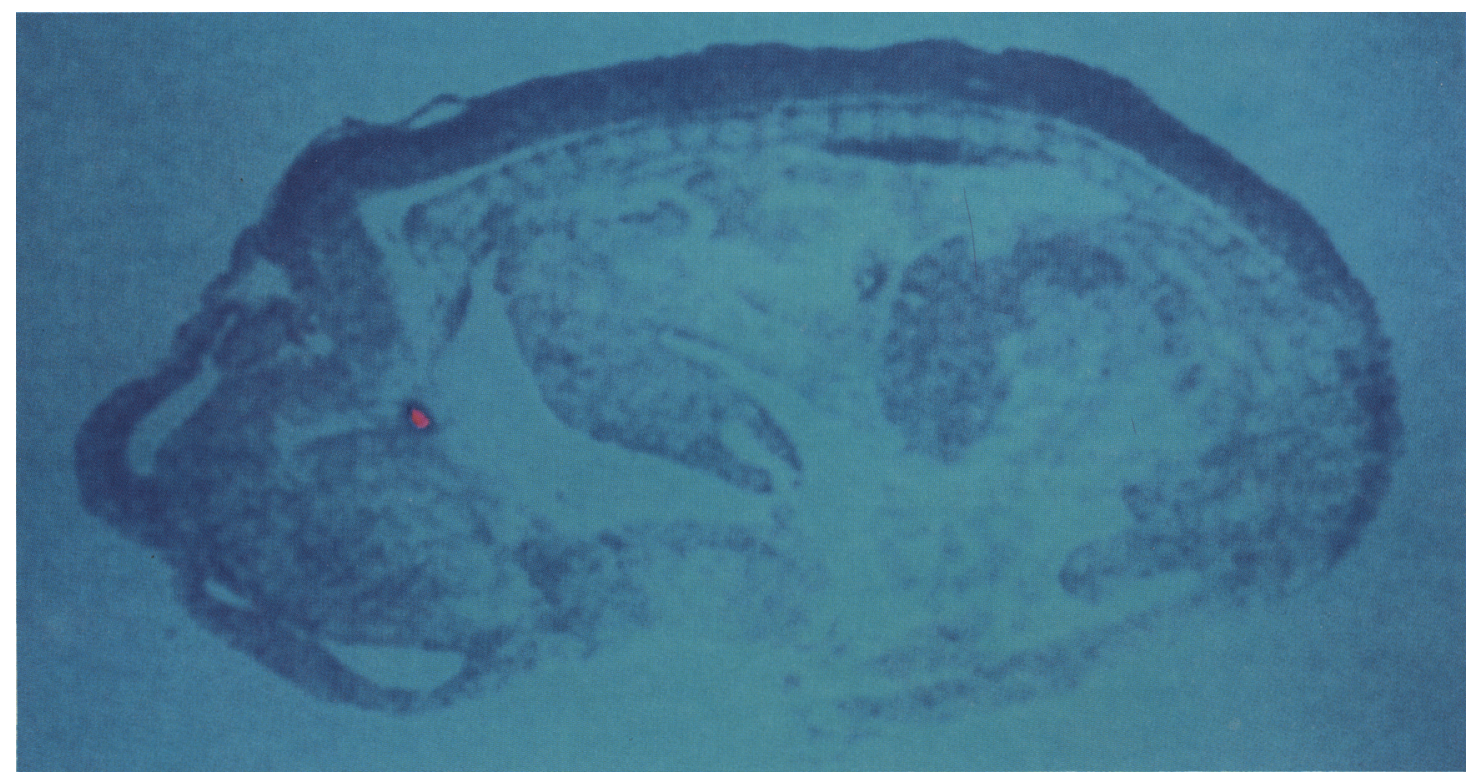

Figure 8. In situ hybridization of Pit-1 in e16 rat embryos. A parasagittal section through an el6 rat embryo was hybridized with a ${ }^{35}$ S-labeled Pit-1 RNA probe $\left(0.37-\mathrm{kb}\right.$ probe directed against the $5^{\prime}$ end of cDNA), and exposed to film, and the resulting autoradiograph was subjected to computer-enhanced image analysis to produce this pseudocolor image. Strongly hybridized signal restricted to the pituitary (red); nonspecific background of the embryonic rat section (dark blue).

pearance of prolactin from e21 to just after birth in the rat (Chetelain et al. 1979; Watanabe and Diakoku 1979) and 8 days postpartum in the mouse (Slabaugh et al. 1982). This apparent discrepancy between the appearance of Pit-1 and the initial expression of prolactin was puzzling; cloned Pit-1 that is expressed in HeLa cells can activate prolactin expression in transient transfection assays (Ingraham et al. 1988), so why should the prolactin expression during development lag behind Pit-1 expression by several days? One possible explanation is that low levels of prolactin expression are activated by Pit-1 very early in development, but other factors cooperate with Pit-1 to generate levels of expression that were detectable in previous reports. We addressed the apparent discrepancy between the expression of Pit-1 and prolactin using the exquisitely sensitive assays for the expression of the transgenic marker genes, luciferase and hGH.

Figure 9 shows that both the D/P-Luc and the 3KBhGH fusion genes were expressed initially at el6 of the mouse. Expression levels rose by greater than an order of magnitude by birth and continued to increase logarithmically until approximately 2 weeks postparturition. Expression of the transgene first appeared at e16 in both $3 \mathrm{~KB}-\mathrm{hGH}$ and $\mathrm{D} / \mathrm{P}$-Luc, indicating that the ontogeny of expression was independent of the marker gene employed. Although it is difficult to compare Pit-1 expression directly in rats with prolactin expression in mice, developmental stages in rats generally occur a day later than in mice. Therefore, the expression of prolactin transgenes on mouse day el6 would be extrapolated to rat day e17. These analyses indicate that prolactin gene expression is activated at low levels in the rodent fetus, closely following the expression of Pit-1 during ontogeny.

\section{Discussion}

In this paper we show that a distal enhancer and a proximal region of prolactin are both capable of directing tissue-specific expression, but synergistic interactions between these elements are necessary for the full physiological levels of expression. Using cell transfectional analyses, previous reports have suggested that either the distal enhancer (Elsholtz et al. 1986; Nelson et al. 1986, 1988 ) or the proximal regions (Lufkin and Bancroft 1987) play the dominant role in directing tissue-specific expression in pituitary cell lines. Because these cell lines alter their characteristics after passaging in cell culture (Bancroft 1981), it is likely that many of the discrepancies in the cell transfectional analyses are the result of differences in the cell lines maintained in different laboratories. In transgenic mice, the proximal region alone is capable of directing the expression of transgenes to the pituitary in a few integration events using the hGH marker gene, but the distal enhancer is crucial for physiological levels of expression. With the luciferase marker gene, the proximal elements are not capable of directing any expression to the pituitary and show an absolute requirement for the distal enhancer. Because all marker genes potentially can contain sequences that contribute to the expression of the transgene, we have used two different marker genes for these analyses. Despite some quantitative differences between constructs containing the two marker genes, the data clearly show that synergistic interactions between the proximal and distal en- 
hancer are important for high levels of prolactin fusion gene expression. We suggest that differences in the penetrance of P-hGH and P-Luc may reflect the fact that cDNA constructs are not transcribed as well as genomic constructs in transgenic mice (Brinster et al. 1988), and that the differences are not the result of a specific contribution of the hGH marker to pituitary expression.
Furthermore, we note that several pedigrees of 3KB-Luc and D/P-Luc mice, which initially expressed high levels of luciferase activity, lost the ability to express the transgene in later generations, whereas no such loss has been detected among pedigrees containing the hGH marker gene.

While examining the role of the distal and proximal

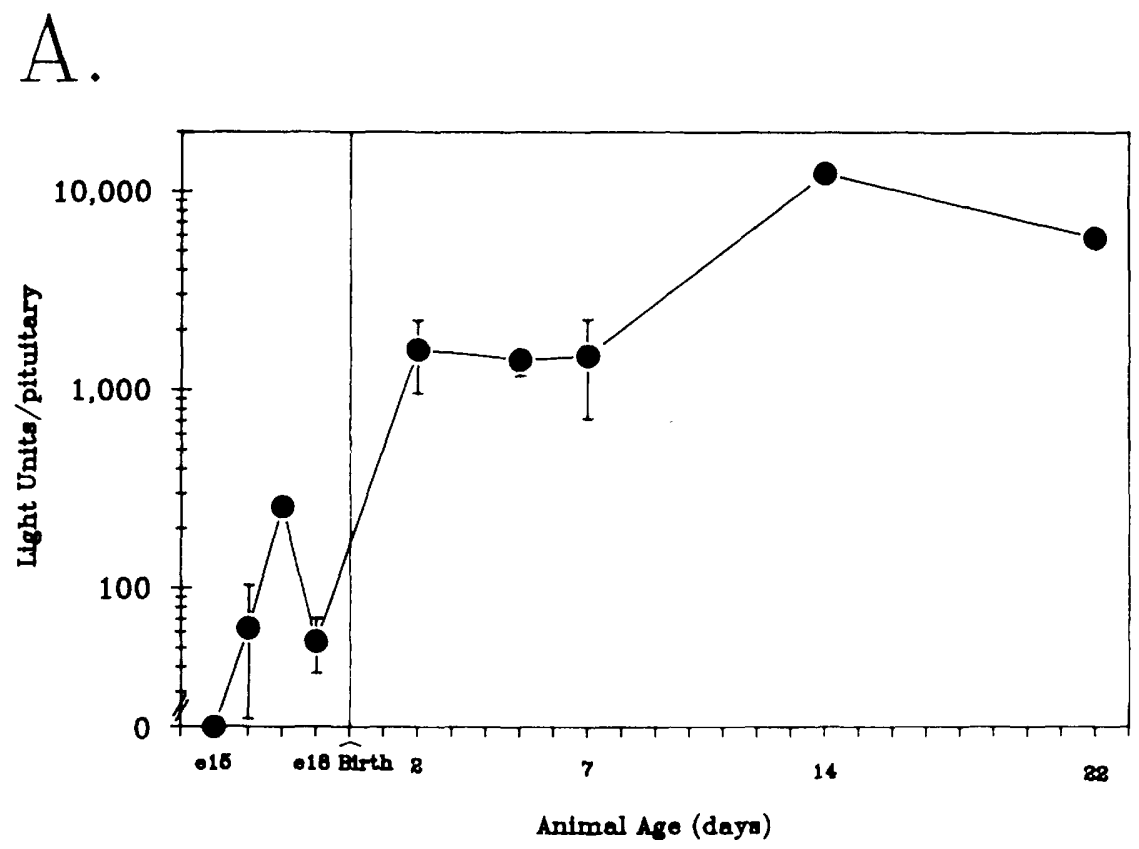

B.



Figure 9. Ontogeny of prolactin transgene expression. $(A)$ Ontogeny of luciferase activity from a D/P-Luc mouse. The ordinate represents a logarithmic scale of light units/pituitary; the abscissa represents developmental age in days. For litters that are $>4$ days old, each point represents the mean light units/pituitary of individual transgenic animals from one or two litters. In litters $<4$ days old, all the pituitaries of a single litter were pooled, and the total amount of light units in the pool was divided by the number of positive transgenic animals in a litter. Therefore, points represent either the average value from a single litter (no error bars) or the mean of two to three litters of the same age (with error bars). In all cases, the error bars represent standard error. The limits of detection for the assay were $\sim 15$ light units/pituitary for an average size litter. $(B)$ Levels of the hGH reporter during the ontogeny of $3 \mathrm{~KB}$-hGH mice. Litters were collected as described in $A$. The limits of detection were $\sim 25 \mathrm{pg} \mathrm{hGH} /$ pituitary for an average size litter. 
regions in prolactin expression, we have shown that the context of the distal enhancer is important for the strict cell-type-specific expression of the prolactin gene within the pituitary. While constructs containing $3 \mathrm{~kb}$ of $5^{\prime}$ flanking region or the proximal region $(-422$ to $+33 \mathrm{bp})$ alone direct strict cell-type-specific expression, constructs containing the distal enhancer removed from its normal context direct expression to both lactotrophs and thyrotrophs. Inquiry into the molecular basis for the dual cell-type specificity of the distal enhancer indicates that both of these cell types express the transcription factor Pit-1. Although evidence for the close relationship between somatotrophs and lactotrophs has been suggested by several types of experiments, the coexpression of Pit-1 provides molecular evidence of a relationship between lactotrophs and thyrotrophs. At this time, it is not clear whether there is a phenotypic difference among thyrotrophs that accounts for Pit-1 expression in a subset of this cell type or whether some thyrotrophs express Pit-1 at levels below our limits of detection by hybridization histochemistry.

To delineate further the role that Pit-1 plays in pituitary development, we analyzed the ontogeny of Pit-1 expression and found that the Pit-1 factor was expressed early in the development of the pituitary. Because prolactin has been reported initially to be detected during the postnatal period, we wished to address the discrepancy between the appearance of Pit-1 expression and previous reports of the ontogeny of prolactin expression. Due to the sensitivity of the assays for transgenic fusion gene markers, we were able to detect the expression of prolactin transgenes much earlier in development than had been reported previously and on a time scale consistent with the developmental activation by Pit-1. Although the $3 \mathrm{~KB}-\mathrm{hGH}$ construct faithfully recapitulates the prolactin expression pattern by all other criteria, we cannot rule out the possibility that the developmental regulation of the transgene may be uncoupled from that of the endogenous gene due to its heterologous chromosomal position. Slabaugh et al. (1982), who detected prolactin initially at postnatal day 8 in the mouse, suggested that estrogen may be responsible for the activation of prolactin during ontogeny. They showed that prolactin expression increased in parallel with progressively higher levels of the estrogen receptor in developing neonates, and that estrogen administration to mouse neonates induced detectable levels of prolactin earlier in pituitary ontogeny. Because expression of prolactin transgenes rose rapidly during this period, we propose that estrogen administration to mouse neonates merely increased the expression of prolactin above the threshold of the detection methods that were available at that time. These results suggest that the initial activation of prolactin is dictated by Pit-1, but other factors, such as the estrogen receptor, may be responsible for the vast increases in prolactin expression that occur during growth into adulthood. Although the $3 \mathrm{~KB}$ constructions mimic the expression of the endogenous prolactin gene accurately, the alternative possibility that the developmental expression of the transgene is in some way uncoupled from normal restriction due to its heterologous position cannot be excluded.

A model for the cell-type-specific expression of the prolactin gene is depicted in Figure 10. Previously it has been postulated that Pit-1 binding sites, found throughout the distal enhancer and proximal region, are responsible for the initial activation of expression during the ontogeny of the pituitary (Nelson et al. 1988; Mangalam et al. 1989). The cloned Pit-1 gene product was shown previously to bind to its cognate sites in both

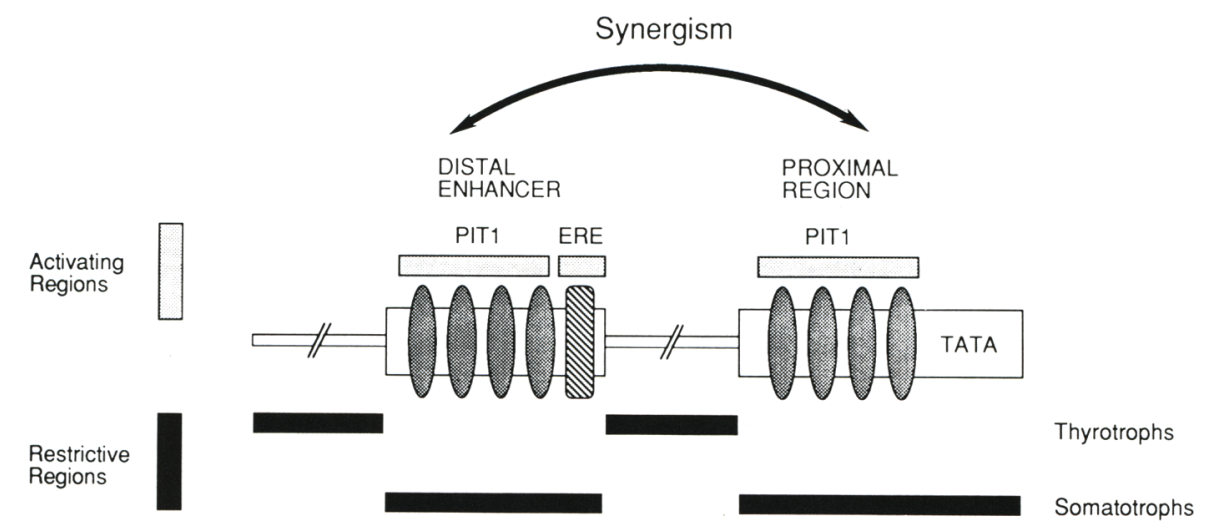

Figure 10. A model for prolactin expression. The precise cell-type specificity of prolactin gene expression is regulated by regions that activate transcription (stippled bars) and restrict transcription from thyrotophs and somatotrophs (black bars). The activating regions are the distal enhancer and the proximal region (open boxes) that must act synergistically to direct full physiological levels of expression in the pituitary gland. These activating regions contain several components: the estrogen regulatory element (ERE; hatched box), the TATA box, and the Pit-l binding sites (stippled ellipses). Because Pit-l is found in several pituitary cell types and binds to both the growth hormone gene and the prolactin gene, there must be restrictive regions that prevent the expression of prolactin in thyrotrophs and somatotrophs. As shown in this paper, the sequences flanking the distal enhancer are necessary to prevent expression in thyrotrophs. Because both the distal and the proximal elements alone direct expression to the appropriate cell type, we propose that there are restrictive elements within each of these regions that prevent Pit-1-mediated expression in somatotrophs. Restriction within these regions may represent negative regulation or the lack of complementing factors necessary for lactotroph expression. 
prolactin and growth hormone promoters, and activate prolactin fusion gene expression in heterologous cells, even when the levels of transfected Pit-1 are 10-fold less than pituitary cell lines (Ingraham et al. 1988; H. Mangalam et al., in prep.). Although it has been reported that a $\operatorname{trpE-Pit-1}$ fusion protein or partially purified Pit-1 preparations fail to bind prolactin promoter elements (Bodner et al. 1988; Castrillo et al. 1989), our laboratory found that intact Pit-1, which was expressed in bacteria, bound to both the distal and proximal regions of prolactin promoter, as well as growth hormone promoter (Mangalam et al. 1989). Because Pit-1 is capable of activating the expression of both growth hormone and prolactin fusion genes (Ingraham et al. 1988) and is found in somatotrophs, lactotrophs (Bodner et al. 1988; Ingraham et al. 1988), and thyrotrophs, there are likely to be restrictive mechanisms that prevent the expression of prolactin in two of the three cell types. The restrictive mechanisms that prevent prolactin expression in somatotrophs must fall within both the distal and the proximal regions, because neither of these regions, which bind Pit-1, direct expression in somatotrophs. Conversely, because Pit-1 is expressed in lactotrophs and does not activate growth hormone expression in this cell type, it is likely that there are cell-specific restrictive mechanisms that regulate the expression of the growth hormone promoter in lactotrophs. Restrictive mechanisms could represent either negative regulation or the lack of complementing factors that interact with Pit-1 to give physiological levels of expression. These results do not exclude the possibility that there are additional factors that bind to the prolactin 5 -flanking region and play pivotal roles in regulating prolactin gene expression. Independent of the molecular mechanisms that activate prolactin expression, sequences flanking the distal enhancer are capable of restricting expression from thyrotrophs as shown in this study. Because the positive regulatory effects of Pit-1 on the prolactin gene are suppressed in somatotrophs and thyrotrophs, this model would predict that the differentiated state of each Pit-1expressing cell type would be dictated by the restrictive mechanisms. The role of Pit-1 during the organogenesis of the pituitary may be to activate transcription in a pituitary-specific manner, whereas the restrictive mechanisms are responsible for delineating cell type within the pituitary. Because both lactotrophs and somatotrophs express Pit-1, a factor that can activate both prolactin and growth hormone promoters, the determination of the restrictive mechanisms that regulate the differentiation of these pituitary cell types should provide an important paradigm for differentiation during mammalian development.

\section{Materials and methods}

\section{Plasmid construction and production of transgenic mice}

The endogenous BamHI site at +2 of the hGH gene was converted by addition of a HindIII linker, and the HindIII-EcoRI fragment of hGH was inserted into the prolactin-promoter constructs. Details of the promoter constructs are given in
Nelson et al. (1986) and Elsholtz et al. (1986). The hGH genomic sequences were a generous gift of P. Seeburg. The D/TK construct contained a slightly longer distal enhancer region in $\mathrm{D} / \mathrm{TK}(-1952$ to -1530$)$ than in the $\mathrm{D} / \mathrm{P}$ constructs $\mid-1831$ to -1530 ). The shorter and the longer enhancer regions express at equivalent levels after transfection into pituitary cell lines (Nelson et al. 1986). The luciferase reporter gene was from the pSV2/L $\Delta 5^{\prime}$ plasmid (a generous gift from S. Subramani; de Wet et al. 1987). All promoter constructs are flanked on the $5^{\prime}$ side with a BamHI site. For injection, most fragments using hGH as a marker were excised and isolated from the vector sequences by digesting with $B a m H I$ and EcoRI. Because the TK promoter contained an internal EcoRI site, fragments from TK-hGH and D/TK-hGH were excised with BamHI and SphI. Fragments using luciferase as a marker gene were excised as BamHI fragments.

Microinjection into fertilized (C57BL/6) $\times \mathrm{DBA} / 2 \mathrm{~J} / \mathrm{F}_{1}$ eggs and transfer to pseudopregnant females was done as described previously (Hogan et al. 1986; Crenshaw et al. 1987). Transgenic mice were identified by dot-blot analysis of DNA extracted from a segment of the tail as described by Palmiter et al. (1982). A specific DNA probe was the internal PvuII fragment from the hGH gene, the SV40-specific BamHI fragment of pSV2-CAT-2 (specific for the splicing and polyadenylation signals from SV40), or the whole pSV2/L plasmid (de Wet et al. 1987). Fragments were labeled to high specific activity by the random priming method (Feinberg and Vogelstein 1983).

\section{hGH assays}

Hormonal determinations were performed with a immunoradiometric assay specific for hGH (Hybritech, La Jolla, California). Mouse growth hormone does not interfere with the assay, even at a $1: 6$ dilution of pituitary extracts. Animals were sacrificed by decapitation, pituitaries were dissected rapidly and triturated 10 times with a 25-gauge hypodermic needle in $150 \mu \mathrm{l}$ of $100 \mathrm{mM} \mathrm{KPO} 4$ buffer. Extracts were frozen and thawed three times and spun in a microfuge for $10 \mathrm{~min}$ at $4^{\circ} \mathrm{C}$. Supernatants were removed and stored at $-70^{\circ} \mathrm{C}$ until the time of the assay. Protein determinations in the extracts were performed by the Lowry method as described by Peterson (1983).

For the analysis of ontogeny, fetal pituitaries of a single litter were combined into one tube and triturated in phosphate buffered saline (PBS). DNA from the placentas was extracted, the number of positive mice was determined by dot-blot hybridization, and nanograms per transgenic pituitary were determined. The lower limit of detection was $\sim 25 \mathrm{pg}$ for an average-sized litter (approximately eight mice per litter with four transgenic fetuses).

Solution hybridization analysis of hGH mRNA was performed as described previously with some modifications (Ornitz et al. 1985). The antisense oligonucleotide used consisted of a segment that hybridizes to the fourth exon of hGH at a position of significant divergence between human and mouse growth hormone (TAGGAGGTCATAGACGTTGCTGTCA). A second modification of the previous protocol involved the use of mung bean nuclease, instead of $S 1$ nuclease, to digest the unhybridized probe, which gave us a two- to fourfold increase in sensitivity. In this case, the same $10 \times$ nuclease buffer was used, but was diluted $30 \times$ for mung bean nuclease digestion.

\section{Luciferase assays}

Large tissues (liver, kidney, gut, brain, spleen, heart, lung, gonads, abdominal wall, submandibular gland, stomach, skeletal muscle, and thymus) were homogenized for $5 \mathrm{sec}$ in a Poly- 
tron (Brinkmann Instruments) in $3 \mathrm{ml}$ of extraction buffer [100 mM potassium phosphate (pH 7.8), $1 \mathrm{~mm}$ dithiothreitol]. Small tissues, such as the pituitary gland, were triturated 10 times through a 25-gauge hypodermic needle in $150 \mu$ l of extraction buffer. Extracts were frozen and thawed three times, and tissue debris was removed by centrifugation for $5 \mathrm{~min}$ at $4^{\circ} \mathrm{C}$ in a microfuge. Fifty micrograms of protein was assayed in a final volume of $200 \mu \mathrm{l}$ of reaction cocktail [final concentration: 100 $\mathrm{mM}$ potassium phosphate ( $\mathrm{pH} 7.8$ ), $10 \mathrm{mM} \mathrm{MgCl}_{2}, 5 \mathrm{~mm} \mathrm{ATP]}$. Light activity was measured in a Monolight 2001 Luminometer (Analytical Luminescence Laboratories, San Diego, California), which initiated reaction by injection of $100 \mu \mathrm{l}$ of $1 \mathrm{mM}$ luciferin. The signal was integrated for $10 \mathrm{sec}$ and represented as arbitrary light units. Control experiments, in which luciferase was added to the tissues prior to homogenization, indicate that $>90 \%$ of the activity was recovered from most tissues. In digestive organs, such as stomach and gut, the recovery was $30-50 \%$. Other organs with $<90 \%$ recovery were the liver and submandibular gland.

For studies of ontogeny, pituitaries from a single litter were pooled and processed as above. Fetal age of mice is based on timed matings with the day of the plug designated day 1 . Analysis of placental DNA was subjected to dot-blot hybridization to determine the number of transgenic animals in the litter, and the light units per transgenic pituitary were determined. The limits of the assay are $\sim 15$ light units/pituitary for an average sized litter (approximately eight mice per litter with four transgenic fetuses).

\section{Immunohistochemistry}

Animals were anesthetized with chloral hydrate and perfused through the heart with paraformaldehyde-glutaraldehyde solutions as described (Swanson et al. 1983). The pituitary glands were removed and postfixed in $4 \%$ paraformaldehyde $/ 0.1 \%$ glutaraldehyde $(\mathrm{pH} 9.5)$ with $10 \%$ sucrose overnight at $4^{\circ} \mathrm{C}$. The pituitaries were frozen on dry ice and $20-\mu \mathrm{m}$ thick sections were cut on a sliding microtome. Free-floating sections then were processed for indirect immunofluorescence, using conventional methods described in detail elsewhere (Swanson et al. 1983). Stained sections were mounted on glass slides with $50 \%$ glycerol ( $\mathrm{pH} 8.6)$, and viewed with a Leitz Dialux 20 fluorescence microscope. The antiserum against hGH was generated in guinea pig (Arnel Products, New York) and used at a $1: 20,000$ dilution. Immunostaining in transgenic pituitaries was blocked completely by preabsorption of the antiserum with $\mathrm{hGH}$ and no staining was observed in control pituitaries. The possibility that the colabeling was the result of immunological cross-reactivity was ruled out by analysis of transgenic animals carrying a 1.5-kb vasopressin $5^{\prime}$-flanking region fused to a hGH marker. The posterior and intermediate lobes of the pituitary stained intensely for hGH but not for TSH, prolactin, or LH. For the detection of endogenous growth hormone in mouse somatotrophs, we used a monkey-anti mouse growth hormone antibody provided by Dr. W.P. Vanderlaan (Whittier Institute, La Jolla, California) at a $1: 25,000$ dilution. An anti-rat LH antiserum generated in rabbit (Dr. A.F. Parlow, National Institute of Diabetes and Digestive and Kidney Disease, Bethesda, Maryland) was used at a $1: 10,000$ dilution. The rabbit anti-human ACTH antibody was a gift from Dr. Wylie Vale (Salk Institute. La Jolla, California) and was used at a $1: 10,000$ dilution. The prolactin antiserum was generated in rabbit against the rat hormone and was obtained from the National Institute of Arthritis and Muscle, Skeletal, and Skin Diseases (NIAMS, Bethesda, Maryland) (used at 1:20,000 dilution). Secondary antisera raised in goats (labeled with fluorescein or rhodamine) against guinea pig $(1: 200)$, human $(1: 100)$, or monkey $(1: 200)$ IgG were purchased from Cappel (Malvern, Pennsylvania). We used antisera generated in goats against rabbit IgG conjugated with fluorescein or rhodamine at a $1: 200$ dilution (Tago, Burlingame, Louisiana). Antiserum to human TSH was generated in rabbits (Bioproducts, Westbury, New York) and used at a $1: 5,000$ dilution. This antiserum does not cross-react with hGH even when used at a $1: 500$ dilution.

\section{Immunohistochemistry/hybridization histochemistry of rat tissue}

Adult male Sprague-Dawley rats were perfused with $4 \%$ paraformaldehyde, as described in Simmons et al. (1989). For fetal perfusions, pregnant rats were perfused as above, and the fetuses were postfixed in $4 \%$ paraformaldehyde overnight at $4^{\circ} \mathrm{C}$. For rat fetal material, the day that the vaginal plug was detected is designated day 0 . Cryostat sections $(10 \mu \mathrm{m})$ of the adult pituitary were mounted on slides coated with gelatin and poly-L-lysine and then vacuum-dried. Then they were incubated for $1 \mathrm{hr}$ at $41^{\circ} \mathrm{C}$ in $0.02 \mathrm{M} \mathrm{KPO}_{4}, 0.9 \% \mathrm{NaCl}$ containing $2 \%$ BSA (Sigma fraction V), $0.3 \%$ Triton X-100, $1 \mathrm{mM}$ dithiothreitol (DTT), 5 $\mathrm{mg} / \mathrm{ml}$ of heparin and $50 \mathrm{U} / \mathrm{ml}$ of RNasin (Boyer et al. 1983). After rinsing in KPBS, sections were incubated for $48 \mathrm{hr}$ at $4^{\circ} \mathrm{C}$ in primary antibodies [rabbit anti-prolactin at $1: 4000$ (NIAMS), rabbit anti-ovine growth hormone at $1: 3000$ (Immunonuclear), and rabbit anti-rat thyroid-stimulating hormone at $1: 1500$ (NIDDKD)] containing $5 \mathrm{mg} / \mathrm{ml}$ of heparin. Antibody binding was visualized using the Vector $A B C$ peroxidase procedure and a modified cobalt intensification method $(\mathrm{Sa}-$ kanaka et al. 1987). Sections were placed serially in $0.1 \mathrm{M}$ Tris, $0.05 \mathrm{M}$ EDTA, $0.5 \%$ Triton $\mathrm{X}-100$, and an ascending series of alcohols, and then air-dried. They were pretreated for $30 \mathrm{~min}$ in hybridization solution minus probe $[50 \%$ formamide, $10 \% \mathrm{dex}$ tran sulfate, $0.3 \mathrm{M} \mathrm{NaCl}, 1 \times$ Denhardt's solution, $10 \mathrm{mM}$ Tris (pH 8.0), $1 \mathrm{mM}$ EDTA, $500 \mu \mathrm{g} / \mathrm{ml}$ tRNA, $1 \mathrm{mM}$ DTT], then hybridized for $48 \mathrm{hr}$ with two changes of hybridization solutions containing $5 \times 10^{6} \mathrm{cpm} / \mathrm{ml}$ of Pit-1 single-stranded RNA synthesized with $\left[{ }^{35} \mathrm{~S}\right] \mathrm{UTP}$. Rat fetuses were sectioned by a cryostat at $20 \mu \mathrm{m}$, pretreated with Triton X-100, dehydrated, and hybridized overnight. Post-hybridization washes included treatment with RNase A $(10 \mu \mathrm{g} / \mathrm{ml})$ and $30 \mathrm{~min}$ in $0.1 \times$ standard saline citrate at $55^{\circ} \mathrm{C}$. Dry sections were dipped in Kodak NTB-2 autoradiography emulsion (diluted $1: 1$ ) and after 10 days of exposure at $4^{\circ} \mathrm{C}$ were developed in Kodak D-d19.

Pit-1 RNA probes were synthesized from pBluescript SKbased vectors (Stratagene). Probes consisted of either a $0.37-\mathrm{kb}$ EcoRI fragment from the coding region at the $5^{\prime}$ end of the cDNA, a 0.55-kb EcoRI fragment from the internal part of the coding region that contains the homeo box, a $1.2-\mathrm{kb} E c o \mathrm{RI}$ fragment of the cDNA that contains only 3 '-untranslated region, or a combination of these three probes (Ingraham et al. 1988). Qualitative results are equivalent with all three probes, but the combination of all probes provides the greatest quantitative signal.

\section{Acknowledgments}

We thank Stacey Dillon, Jodi Harrold, and Beth Rawson for their excellent technical assistance. Particularly, we thank Holly Ingraham for initiating the analysis of the ontogeny of Pit-1 expression; Chris Nelson, Harry Elsholtz, Mark Stamnes, Sally Durgerian, and Sergio Lira for their suggestions and contributions throughout this project; Sen $\mathrm{Li}$ and Tara Rachinsky for critical reading of the manuscript; Alan G. Watts for developing the immunohistochemistry/in situ hybridization double- 
label protocol; Frank Costantini, Liz Lacy, and Brigid Hogan for instruction on transgenic mouse production; Peter Seeburg for providing the hGH plasmid; and Suresh Subramani for providing the luciferase plasmid. This work was supported grants from the National Institutes of Health and the Howard Hughes Medical Institute.

\section{References}

Akam, M. 1987. The molecular basis for metameric pattern in the Drosophila embryo. Development 101: 1-22.

Bancroft, F.C. 1981. GH cells: Functional clonal lines of rat pituitary tumor cells. In Functionally differentiated cell lines. (ed. G. Sato), pp. 47-59, Alan R. Liss, New York.

Behringer, R.R., L.S. Mathews, R.D. Palmiter, and R.L. Brinster. 1988. Dwarf mice produced by genetic ablation of growth hormone-expressing cells. Genes Dev. 2: 453-461.

Bodner, M. and M. Karin. 1987. A pituitary-specific trans-acting factor can stimulate transcription from the growth hormone promoter in extracts of nonexpressing cells. Cell 50: 267 275.

Bodner, M., J.-L. Castrillo, L.E. Theill, T. Deerinck, M. Ellisman, and M. Karin. 1988. The pituitary-specific transcription factor GHF-1 is a homeobox-containing protein. Cell 55: $505-518$.

Boyer, S.H., K.D. Smith, A.N. Noyes, and K.E. Young. 1983. Adjuvants to immunological methods for mRNA purification. Application to the isolation of mRNA for carbonic anhydrase I from rabbit reticulocytes. I. Histochem. 258: 2068-2071.

Brinster, R.L., J.M. Allen, R.R. Behringer, R.E. Gelinas, and R.D. Palmiter. 1988. Introns increase transcriptional efficiency in transgenic mice. Proc. Natl. Acad. Sci. 85: 836-840.

Cao, Z., E.A. Barron, A.J. Carrillo, and Z.D. Sharp. 1987. Reconstitution of cell-type-specific transcription of the rat prolactin gene in vitro. Mol. Cell Biol. 7: 3402-3408.

Castrillo, J.-L., M. Bodner, and M. Karin. 1989. Purification of growth hormone-specific transcription factor GHF-1 containing homeobox. Science 243: 814-817.

Chetelain, A., I.P. Dupuoy, and M.P. Dubois. 1979. Ontogenesis of cells producing polypeptide hormones (ACTH, MSH, LPH, GH, Prolactin) in the fetal hypophysis of the rat: Influence of the hypothalamus. Cell and Tiss. Res. 196: 409-427.

Clerc, R.G., L.M. Corcoran, J.H. LeBowitz, D. Baltimore, and P.A. Sharp. 1988. The B-cell specific Oct- 2 protein contains POU box and homeo box-type domains. Genes Dev. 2: $1570-1581$.

Cooke, N.E., D. Coit, R.I. Weiner, I.D. Baxter, and J.A. Martial. 1981. Human prolactin: Structural analysis and evolutionary comparisons. J. Biol. Chem. 256: 4007-4016.

Crenshaw, E.B., III, A.F. Russo, L.W. Swanson, and M.G. Rosenfeld. 1987. Neuron-specific alternative RNA processing in transgenic mice expressing a metallothionein-calcitonin fusion gene. Cell 49: 389-398.

de Wet, J.R., K.V. Wood, M. DeLuca, D.R. Helinski, and S. Subramani. 1987. Firefly luciferase gene: structure and expression in mammalian cells. Mol. Cell Biol. 7: 725-737.

Elsholtz, H.P., H.J. Mangalam, E. Potter, V.R. Albert, S. Supowit, R.M. Evans, and M.G. Rosenfeld. 1986. Two different cis-active elements transfer the transcriptional effects of both EGF and Phorbol esters. Science 234: 1552-1557.

Feinberg, A.P. and B. Vogelstein. 1983. A technique for radiolabeling DNA restriction endonuclease fragments to high specific activity. Anal. Biochem. 132: 6-13.
Finney, M., G. Ruvkin, and H.R. Horvitz. 1988. The C. elegans cell lineage and differentiation gene unc-86 encodes a protein containing a homeodomain and extended sequence similarity to mammalian transcription factors. Cell 56: 757769.

Frawley, L.S., F.R. Boockfoor, and J.P. Hoeffler. 1985. Identification by plaque assays of a pituitary cell type that secretes both growth hormone and prolactin. Endocrinology 116: $734-737$.

Gehring, W.J. 1987. Homeoboxes in the study of development. Science 236: 1245-1252.

Gutierrez-Hartmann, A., S. Siddiqui, and S. Loukin. 1987. Selective transcription and DNase I protection of the rat prolactin gene by $\mathrm{GH}_{3}$ pituitary cell-free extracts. Proc. Natl. Acad. Sci. 84: 5211-5215.

He, X., M.N. Treacy, D.M. Simmons, H.A. Ingraham, L.W. Swanson, and M.G. Rosenfeld. 1989. Expression of a large family of POU-domain regulatory genes in mammalian brain development. Nature (in press).

Herr, W., R.A. Sturm, R.G. Clerc, L.M. Corcoran, D. Baltimore, P.A. Sharp, H.A. Ingraham, M.G. Rosenfeld, M. Finney, G. Ruvkun, and H.R. Horvitz. 1988. The POU domain: A large conserved region in the mammalian Pit-1, Oct-1, Oct-2, and Caenorhabditis elegans unc-86 gene products. Genes Dev. 2: $1513-1516$

Hoeffler, I.P, F.R. Boockfor, and L.S. Frawley. 1985. Ontogeny of prolactin cells in neonatal rats: initial prolactin secretors also release growth hormone. Endocrinology 117: 187-195.

Hogan, B., F. Costantini, and E. Lacy. 1986. Manipulating the mouse embryo: A laboratory manual. Cold Spring Harbor Laboratory, Cold Spring Harbor, New York.

Ingraham, H.A., R. Chen, H.J. Mangalam, H.P. Elsholtz, S.E. Flynn, C.R. Lin, D.M. Simmons, L. Swanson, and M.G. Rosenfeld. 1988. A tissue-specific transcription factor containing a homeodomain specifies a pituitary phenotype. Cell 55: 519-529.

Ko, H.-S., P. Fast, W. McBride, and L.M. Staudt. 1988. A human protein specific for the immunoglobulin octamer DNA motif contains a functional homeobox domain. Cell 55: $135-144$.

Lira, S.A., E.B. Crenshaw III, C.K. Glass, L.W. Swanson, and M.G. Rosenfeld. 1988. Identification of rat growth hormone genomic sequences targeting pituitary expression in transgenic mice. Proc. Natl. Acad. Sci. 85: 4755-4759.

Lufkin, T. and C. Bancroft. 1987. Identification by cell fusion of gene sequences that interact with positive trans-acting factors. Science 237: $283-286$.

Mangalam, H.J., V.R. Albert, H.A. Ingraham, M. Kapiloff, L. Wilson, C. Nelson, and M.G. Rosenfeld. 1989. A pituitary POU-domain protein, Pit-1, activates both growth hormone and prolactin promoters transcriptionally. Genes Dev. 3: $946-958$.

Muller, M.M., S. Ruppert, W. Schaffner, and P. Matthias. 1988. A cloned octamer transcription factor stimulates transcription from lymphoid-specific promoters in non-B cells. $\mathrm{Na}$ ture 336: 544-551.

Nelson, C., E.B. Crenshaw III, R. Franco, S.A. Lira, V.R. Albert, R.M. Evans, and M.G. Rosenfeld. 1986. Discrete cis-active genomic sequences dictate the pituitary cell type-specific expression in rat prolactin and growth hormone genes. $\mathrm{Na}$ ture 322: 557-562.

Nelson, C., V.R. Albert, H.P. Elsholtz, L.E.-W. Lu, and M.G. Rosenfeld. 1988. Activation of cell-specific expression of rat growth hormone and prolactin genes by a common transcription factor. Science 239: 1400-1405.

Nikitovitch-Winer, M.B., J. Atkin, and B.E. Maley. 1987. Colo- 


\section{Crenshaw et al.}

calization of prolactin and growth hormone within specific adenohypohhyseal cells in male, female, and lactating female rats. Endocrinology 121: 625-630.

Ornitz, D.M., R.D. Palmiter, R.E. Hammer, R.L. Brinster, G.H. Swift, and R.J. MacDonald. 1985. Specific expression of an elastase-human growth hormone fusion gene in pancreatic acinar cells of transgenic mice. Nature 313: 600-602.

Palmiter, R.D., H.Y. Chen, and R.L. Brinster. 1982. Differential regulation of metallothionein-thymidine kinase fusion genes in transgenic mice and their offspring. Cell 29: 701710.

Peterson, G.L. 1983. Determination of total protein. Methods Enzymol. 91: 95-119.

Pintar, J.E. and D.I. Lugo. 1987. POMC gene expression, prohormone processing and secretion during rat pituitary development. Annu. N.Y. Acad. Sci. 512: 318-327.

Russo, A.F., E.B. Crenshaw III, S.A. Lira, D.M. Simmons, L.W. Swanson, and M.G. Rosenfeld, 1988. Neuronal expression of chimeric genes in transgenic mice. Neuron 1: 311-320.

Sakanaka, M., T. Shibasaki, and K. Lederis. 1987. Improved fixation and cobalt-glucose oxidase- diaminobenzidine intensification for immunohistochemical demonstration of corticotropin-releasing factor in rat brain. I. Histochem. Cytochem. 35: 207-212.

Scheidereit, C., J.A. Cromlish, T. Gerster, K. Kawakami, C.-G. Balmaceda, R.A. Currie, and R.G. Roeder. 1988. A human lymphoid-specific transcription factor that activates immunoglobulin genes is a homoeobox protein. Nature 336: 551 557.

Scott, M.P. and S.B. Carroll. 1987. The segmentation and homeotic gene network in early Drosophila development. Cell 51: $689-698$.

Simmons, D.M., J.L. Arriza, and L.W. Swanson. 1989. Complete protocol for in situ hybridization in brain and other tissues with radiolabeled single-stranded RNA probes. I. Histotechnol. (in press).

Sinha, Y.N., C.B. Salocks, and W.P. Vanderlaan. 1975. Prolactin and growth hormone levels in different inbred strains of mice: Patterns in association with estrous cycle, time of day, and perphenazine stimulation. Endocrinology 97: $1112-1122$.

Slabaugh, M.B., M.E. Lieberman, J.J. Rutledge, and J. Gorski. 1982. Ontogeny of growth hormone and prolactin gene expression in mice. Endocrinology 110: 1489-1497.

Sturm, R.A., G. Das, and W. Herr. 1988. The ubiquitous octamer binding protein Oct- 1 contains a POU domain with a homeo box subdomain. Genes Dev. 2: 1582-1599.

Swanson, L.W., P.E. Sawchenko, J. Rivier, and W.W. Vale. 1983. Organization of ovine corticotropin-releasing factor immunoreactive cells and fibers in the rat brain: An immunohis tochemical study. Neuroendocrinology 36: 165-183.

Watanabe, Y.G. and S. Daikoku. 1979. An immunohistochemical study on the cytogenesis of adenohypophysial cells in fetal rats. Dev. Biol. 68: 557-567.

West, B.L., D.F. Catanzaro, S.H. Mellon, P.A. Cattini, J.D. Baxter, T.L. Reudelhuber. 1987. Interaction of a tissue-specific factor with an essential rat growth hormone gene promoter element. Mol. Cell. Biol. 7: 1193-1197.

Wilson, D.B. and D.P. Wyatt. 1986. Ultrastructural immunocytochemistry of somatotrophs and mammotrophs in embryos of the dwarf mutant mouse. Anat. Rec. 215: 282-287.

Ye, Z.-S. and H.H. Samuels. 1987. Cell- and sequence-specific binding of nuclear proteins to 5 '-flanking DNA of the rat growth hormone gene. J. Biol. Chem. 262: 6313-6317. 


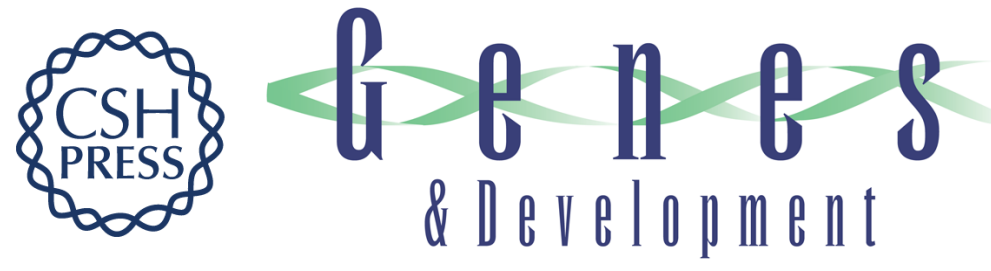

\section{Cell-specific expression of the prolactin gene in transgenic mice is controlled by synergistic interactions between promoter and enhancer elements.}

E B Crenshaw, K Kalla, D M Simmons, et al.

Genes Dev. 1989, 3:

Access the most recent version at doi:10.1101/gad.3.7.959

References This article cites 46 articles, 19 of which can be accessed free at: http://genesdev.cshlp.org/content/3/7/959.full.html\#ref-list-1

License

Email Alerting Service

Receive free email alerts when new articles cite this article - sign up in the box at the top right corner of the article or click here.

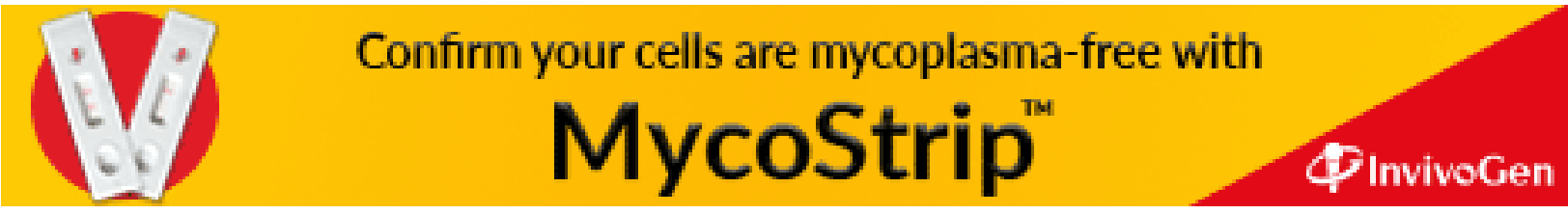

